\title{
TASTE SENSITIVITY TO PTC AND COLOUR BLINDNESS IN ESTONIANS
}

\author{
Leiu Heapost \\ Department of Archaeobiology and Ancient Technology, \\ Institute of History, Tallinn University, Estonia
}

\begin{abstract}
The article discusses the genetic characterisation of Estonians on the basis of the traits of PTC and colour blindness in Estonian population samples from various parts of Estonia.

The taste sensitivity to PTC was studied in 2559 Estonian schoolchildren from 24 localities and of colour blindness in 4300 males from 33 localities. Results: The frequency of nontasters was $25.4 \%$ on average; $t$ gene frequency (50.4\% for Estonians) varied between $36 \%$ and $65 \%$. PTC nontasters frequency is higher on West-Estonian islands and in Western Estonia compared to other parts of Estonia. The frequency of colour blindness $c b$ gene $(5.3 \%$ for Estonians) is higher in North, North-East and East Estonia (6-8\%); its mean frequency on the rest of the territory is lower. The genetic diversity in various traits seem to be a trace of the historical development of the Estonian nation.
\end{abstract}

Key words: PTC, colour blindness, population genetics, Estonians.

\section{INTRODUCTION}

Taste sensitivity to phenylthiocarbamide (PTC) and colour blindness belong to those physiological traits that directly prove genetic diversity of people concerning the perception of the world; they are highly informative genetic markers in the studies of human diversity.

Determing taste sensitivity to PTC begun as early as in 1931, after the chemical substance was synthesized by chemist A. L. Fox. On describing the taste of PTC it appeared that the people tested were divided into two groups; most people tasted it bitter, but to others it was 
without taste. So it was possible to discover polymorphism in the taste sensitivity to PTC, and to divide the human population into "tasters" and "nontasters" [4].

Later the ability to taste the PTC was found to be inherited as a simple Mendelian dominant trait, and nontasting is a simple recessive characteristic, but there are references that the threshold of taste sensitivity is higher in heterozygotes than homozygotes [8]. For studying taste sensitivity, a standard method using serial dilutions of PTC was developed. It appeared that the "tasters" varied greatly according to their sensitivity to taste PTC; everybody has their own threshold (the lowest concentration of PTC where the bitter taste appears), and taste sensitivity in populations has a bimodal distribution, one mode "tasters", the other - "nontasters" [7].

Recent genetic PTC studies have revealed that the ability to taste PTC or not is conveyed by a single gene that codes for a taste receptor on the tongue. The PTC gene, TAS2R38, was discovered in 2003 [15]. Phenotypic variance in PTC sensitivity is accounted for the presence of just two common alleles: a tasting allele and a non-tasting allele, and the frequencies of these alleles in human populations correspond well to frequencies estimated from phenotype data [21].

Inability to clearly identify different colours of the spectrum is widely known as colour blindness. An individual with normal colour vision is capable to distinguish all the primary colours and blend them into different tones of colours. In the case of partial colour blindness, an individual does not distinguish clearly, in most cases, between red and green colour. These colour vision deficiencies are named protanomaly and deuteranomaly, but the inability to perceive red and green colours protanop and deuteranop. Red-green colour blindness is a sex-linked trait; the corresponding genes are situated in the $\mathrm{X}$ chromosome, but normal colour vision is dominant in relation to colour blindness. Therefore, colour blindness is expressed mainly in men. Red and green colour pigments are present at the tip of the long arm of the $\mathrm{X}$ chromosome $\mathrm{Xq} 28$ [17].

In the distribution of colour blindness and PTC taste sensitivity, regional and racial differences occur. Colour blindness is more frequent among the Caucasoid peoples than among the Mongoloids [9]. PTC nontasers appear more frequently among Caucasoid populations. In Mongoloid populations, as Japanese and Chinese, nontasters are con- 
siderably rare and, vice versa, tasters are found there much more frequently [18].

These data have also been referred to in studies of Estonians, and erroneous statements about the occurrence of PTC nontasters in Estonia have been made; the corresponding studies still have to be started [19]. Population genetic studies of 10 polymorphic systems (blood groups, PTC, colour blindness) of the Estonian population have been studied by the author of the present paper, and genetic analyses have been given earlier [11, 12, 5:570, 6:622]. The aim of the current study is to give an overview of the diversity of taste sensitivity to PTC and colour blindness among Estonians.

\section{MATERIAL AND METHODS}

The material used in the present study was gathered by the author mainly during the anthropological expeditions of the Institute of History of the Academy of Sciences in the 1970s and 1980s. The subjects were of Estonian descent; their parents and grandparents came from the same district. Tests were carried out on both schoolchildren and grown-up men. In the case of taste sensitivity to PTC, only the schoolchildren's material (2559 individuals from 24 regional locations) was used to avoid possible errors in the case of older people, and so that the data would be wholly comparable all over Estonia. The ability to detect the bitter taste of PTC was tested using 15 concentrations of PTC solutions, following the technique of Harris and Kalmus [7]. The concentrations of the solutions, in boiled tap water, were obtained by means of the formula $2.6 \times 2-\mathrm{n} g / 1$ (where $\mathrm{n}$ is the number of the solution), whereby in the case of the strongest concentration $n=0$, in the weakest $-n=15$. Tasting was started from the solution with the lowest concentration (no.15). Between every different solution, pure water was given. The threshold for each subject was the lowest concentration at which he was able to distinguish the PTC solution from pure water. Approximately $2 \%$ of schoolchildren did not even feel the bitter taste of the strongest solution $(n=0)$. These people are marked with a negative sign in Fig.1. The distribution of the thresholds shows a typical bimodal shape (Fig.1). The threshold for schoolchildren was solution no. 5. The subjects who felt the taste of PTC solutions no. 15-6 were regarded as "tasters", of no. 5-0 as "nontasters". 
Colour blindness was studied among 4300 males from 33 districts. The colour vision test for red-green colour deficiency among men and schoolboys was carried out by using polychromatic tables by J. Rabkin [24]. The test was conducted in daylight inside a room, avoiding direct sunlight.

\section{RESULTS AND DISCUSSION}

As regards to PTC tasting ability, the data on Estonians exibit a bimodal distribution of the threshold (Fig. 1). Among the 2559 individuals studied, $74.6 \%$ were tasters, $25.4 \%$ did not feel the bitter taste of PTC. The percentage and gene frequency of nontasters is given in Table 1. The frequency of nontasters of PTC, $t$ gene, varies in Estonian different local samples between $36 \%$ and $65 \%$, with the mean frequency $50.4 \%$ ) (Table 1, Fig. 2). In the West Estonian islands the $t$ gene frequency is higher $(60 \%)$ in comparison to the other parts of Estonia. It is also comparatively high in some other westernmost parts of West and SouthWest Estonia (56-57\%). In the East Estonian region (in Alatskivi), in the area between Lake Võrtsjärv and Lakes Peipsi-Pihkva (Pskov) and in some locations of inner Estonia, the frequency is lower (40-53\%) (Fig.2).

Frequency of nontasters of PTC in Estonians is lower in comparison with the Finns; however, on the West Estonian islands and on the West Estonian coast, the percentage of nontasters of PTC is higher, being similar to that of other Finno-Ugric peoples, such as Komis, Maris, Hungarians but also non-Finno-Ugric peoples like Lithuanians, Russians, Swedes, et al. (Table 1, Table 2). Frequency of $t$ gene in Latvians from Varakḷāni is more similar to that of West-Estonian islands, from Alūksne to that of the South-East Estonian population. The frequency of nontasters is somewhat lower in Lapps from Inari and Kola Peninsula. The frequency of $t$ gene is lower in the Mongoloid peoples in Evenks 24\%, Chinese 21\%, etc. At that, taste sensibility to PTC is much higher in Mongoloid peoples who distinguish even a very weak solution (no.28) from pure water [25]. 
Table 1. Frequency of PTC nontasters ( $\%$ and $t$-gene)

\begin{tabular}{|l|c|c|c|c|c|}
\hline \multicolumn{1}{|c|}{$\begin{array}{c}\text { Population } \\
\text { group }\end{array}$} & $\mathrm{N}$ & \multicolumn{2}{c|}{ Phenotype } & \multicolumn{2}{c|}{ Genotype } \\
\cline { 3 - 6 } & & $\mathrm{n}$ & $\%$ & $t$ & $\sigma$ \\
\hline 1. Kuressaare & 116 & 38 & 32,76 & .5724 & .0381 \\
\hline 2. Orissaare & 113 & 47 & 41.59 & .6449 & .0359 \\
\hline 3. Muhu & 103 & 35 & 33.98 & .5829 & .0400 \\
\hline 4. Haapsalu & 110 & 36 & 32.73 & .5721 & .0391 \\
\hline 5. Lihula & 107 & 21 & 19.63 & .4431 & .0433 \\
\hline 6. Tõstamaa & 75 & 21 & 28.00 & .5292 & .0489 \\
\hline 7. Audru & 80 & 20 & 25.00 & .5000 & .0484 \\
\hline 8. Pärnu-Jaagupi & 99 & 31 & 31.31 & .5596 & .0416 \\
\hline 9. Märjamaa & 100 & 15 & 15.00 & .3875 & .0461 \\
\hline 10. Kehra & 100 & 22 & 22.00 & .4690 & .0441 \\
\hline 11. Kunda & 109 & 28 & 25.69 & .5069 & .0413 \\
\hline 12. Iisaku & 154 & 34 & 22.08 & .4699 & .0356 \\
\hline 13. Järva-Jaani & 83 & 13 & 15.66 & .3957 & .0504 \\
\hline 14. Suure-Jaani & 101 & 43 & 42.57 & .6525 & .0377 \\
\hline 15. Alatskivi & 92 & 17 & 18.48 & .4299 & .0471 \\
\hline 16. Elva & 96 & 21 & 21.88 & .4677 & .0451 \\
\hline 17. Võnnu & 67 & 15 & 22.39 & .4732 & .0538 \\
\hline 18. Põlva & 224 & 59 & 26.34 & .5132 & .0286 \\
\hline 19. Värska & 106 & 17 & 16.04 & .4005 & .0445 \\
\hline 20. Meremäe & 123 & 34 & 27.64 & .5257 & .0383 \\
\hline 21. Valga & 98 & 13 & 13.27 & .3642 & .0470 \\
\hline 22. Abja & 97 & 20 & 20.62 & .4541 & .0437 \\
\hline 23. Viljandi & 104 & 18 & 17.31 & .4161 & .0446 \\
\hline 24. Kilingi- & 102 & 32 & 31.37 & .5601 & .0410 \\
Nõmme & & & & & \\
\hline 1-24 in total & 2559 & 650 & 25.40 & .5040 & .0085 \\
\hline
\end{tabular}




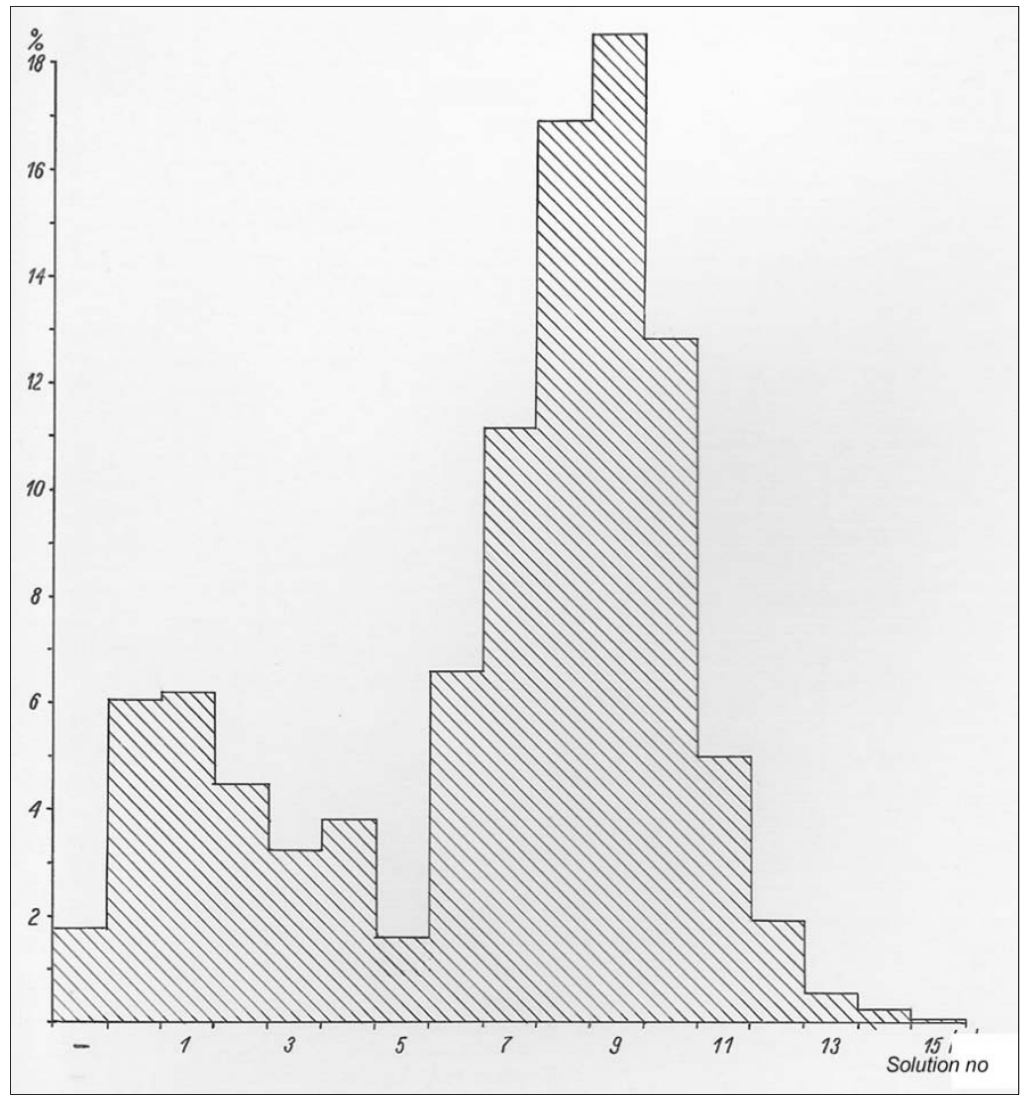

Fig. 1. Taste sensitivity to PTC. 
Table 2. Frequency of PTC nontasters in various populations $(\%$ and $t$-gene)

\begin{tabular}{|l|c|c|c|c|}
\hline Population & $\mathrm{N}$ & $\%$ & $t$-gene & Sources \\
\hline Estonians & 2559 & 25.4 & .504 & {$[11]$} \\
\hline Finns & 811 & 35.0 & .592 & {$[14]$} \\
\hline Finns (Helsinki) & 202 & 29.2 & .541 & {$[1]$} \\
\hline Finns (Oulu) & 761 & 22.1 & .470 & {$[2]$} \\
\hline Lapps (Inari) & 184 & 15.8 & .396 & {$[23]$} \\
\hline Lapps (Kolta) & 149 & 36.2 & .602 & {$[23]$} \\
\hline Lapps (Kola Peninsula) & 124 & 12.5 & .353 & {$[28]$} \\
\hline Vepsians & 176 & 28.4 & .533 & {$[11]$} \\
\hline Komi & 302 & 36.8 & .606 & {$[23]$} \\
\hline Mari & 321 & 26.5 & .514 & {$[23]$} \\
\hline Hungarians & 401 & 32.2 & .567 & {$[3]$} \\
\hline $\begin{array}{l}\text { Hungarians } \\
\text { (Transcarpathian) }\end{array}$ & 203 & 31.5 & .562 & Author's \\
\hline Latvians (Alūksne) & 109 & 24.8 & .498 & {$[11]$} \\
\hline Latvians (Varakḷāni) & 109 & 43.1 & .657 & {$[11]$} \\
\hline Lithuanians & 163 & 31.9 & .565 & {$[26]$} \\
\hline Belarusians & 2694 & 35.6 & .597 & {$[26]$} \\
\hline Russians & 245 & 32.1 & .567 & {$[22]$} \\
\hline Swedes (Åland) & 124 & 33.1 & .575 & {$[13]$} \\
\hline Swedes & 509 & 33.8 & .581 & {$[20]$} \\
\hline Kyrgyz & 640 & 19.6 & .443 & {$[22]$} \\
\hline Evenks & 137 & 5.8 & .241 & {$[25]$} \\
\hline Chinese & 239 & 4.6 & .214 & {$[16]$} \\
\hline
\end{tabular}




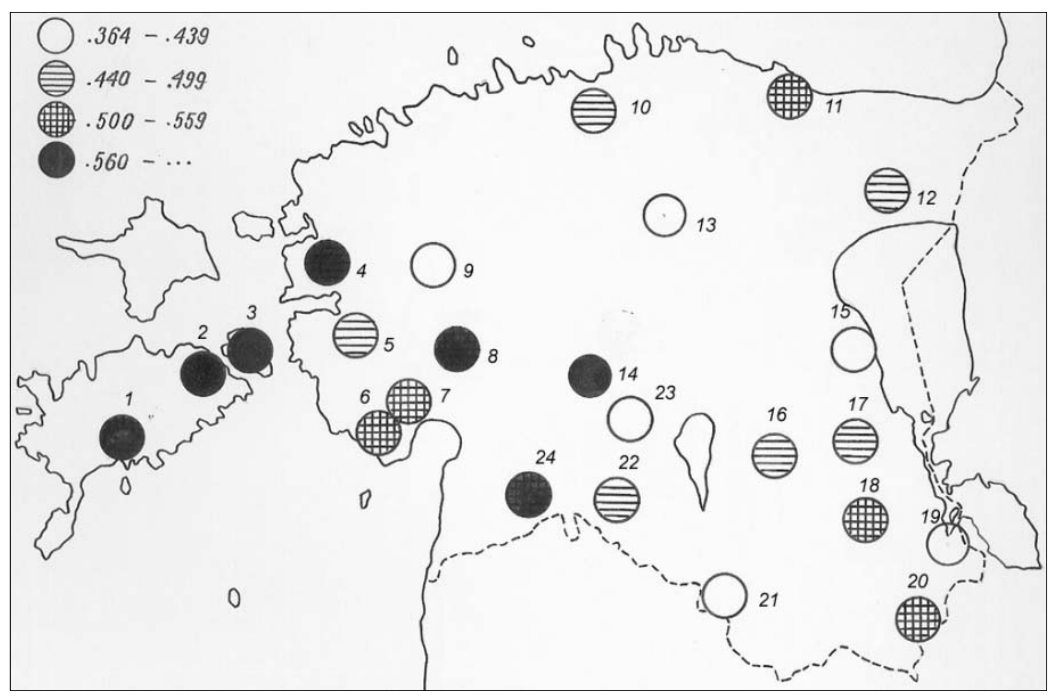

Fig. 2. Distribution of nontaster $(t)$ gene.

Colour blindness. In Estonia, the colour blindness has been studied among male population (grown-up men and schoolboys). For testing colour blindness in Tallinn schools, $7.17 \%$ of schoolboys from 293 tested were found to be colour blind; among them - deuteranomaly $3.1 \%$, protanamaly $1.35 \%$, deuteranop $1.36 \%$ and protanop $1.36 \%$ [10]. These data correspond well with the earlier data by R. I. Serebrovskaya (in 235 males $3.0 \%$ of deuteranomaly and $1.3 \%$ of protanomaly) [27].

Table 3 shows the percentage of incidence of colour blindness. The frequency of colour blindness varies in different Estonian local samples between $2 \%$ and $9 \%$, with the average $5.3 \%$. The frequency is higher in East and North-East Estonia (6-8\%). The frequency of $c b$ gene in West Estonia is comparatively high as well $(6,2 \%)$ and its frequency decreases towards South-East Estonia (Fig. 3). The whole South-East is characterised by low occurrence of colour blindness (on average 4.3\%). It is low on the West Estonian islands and in Central Estonia as well. 
Table 3. Frequency of colour blindness

\begin{tabular}{|l|c|c|c|c|c|}
\hline \multirow{2}{*}{ Population } & \multirow{2}{*}{$\mathrm{N}$} & \multicolumn{2}{|c|}{ Phenotype } & \multicolumn{2}{c|}{ Genotype } \\
\cline { 3 - 6 } & & $\mathrm{n}$ & $\%$ & $c b$ & $\sigma$ \\
\hline 1.Saaremaa, Muhu & 382 & 14 & 3.66 & .0366 & .0096 \\
\hline 2.Hiiumaa & 102 & 5 & 4.90 & .0490 & .0214 \\
\hline 3.Haapsalu & 210 & 13 & 6.19 & .0619 & .0166 \\
\hline 4.Lihula & 158 & 9 & 5.70 & .0570 & .0184 \\
\hline 5.Tõstamaa & 43 & 4 & 9.30 & .0930 & .0443 \\
\hline 6.Audru, Pootsi & 178 & 11 & 6.18 & .0618 & .0180 \\
\hline 7.Pärnu-Jaagupi & 132 & 8 & 6.06 & .0606 & .0208 \\
\hline 8.Rapla & 182 & 8 & 4.40 & .0440 & .0152 \\
\hline 9.Keila & 137 & 8 & 5.84 & .0584 & .0200 \\
\hline 10.Tallinn & 293 & 21 & 7.17 & .0717 & .0151 \\
\hline 11.Kehra & 75 & 5 & 6.67 & .0667 & .0288 \\
\hline 12.Rakvere & 99 & 8 & 8.08 & .0808 & .0274 \\
\hline 13.Kohtla-Järve & 99 & 5 & 5.05 & .0505 & .0220 \\
\hline 14.Iisaku & 147 & 10 & 6.80 & .0680 & .0208 \\
\hline 15.Väike-Maarja & 100 & 8 & 8.00 & .0800 & .0271 \\
\hline 16.Paide & 94 & 2 & 2.13 & .0213 & .0149 \\
\hline 17.Suure-Jaani & 56 & 3 & 5.36 & .0536 & .0301 \\
\hline 18.Põltsamaa & 101 & 4 & 3.96 & .0396 & .0194 \\
\hline 19.Jõgeva & 65 & 5 & 7.69 & .0769 & .0330 \\
\hline 20.Alatskivi & 55 & 4 & 7.27 & .0727 & .0350 \\
\hline 21.Elva & 91 & 4 & 4.40 & .0440 & .0215 \\
\hline 22.Otepää & 99 & 3 & 3.03 & .0303 & .0172 \\
\hline 23.Võnnu & 37 & 2 & 5.40 & .0540 & .0372 \\
\hline 24.Põlva & 295 & 15 & 5.08 & .0508 & .0128 \\
\hline 25.Antsla & 102 & 5 & 4.90 & .0490 & .0214 \\
\hline 26.Võru & 103 & 5 & 4.85 & .0485 & .0212 \\
\hline 27.Värska & 49 & 3 & 6.12 & .0612 & .0342 \\
\hline 28.Petseri & 102 & 2 & 1.96 & .0196 & .0137 \\
\hline 29.Meremäe & 210 & 8 & 3.81 & .0381 & .0132 \\
\hline 30.Valga & 105 & 6 & 5.71 & .0571 & .0226 \\
\hline 31.Abja, Karksi & 196 & 14 & 7.14 & .0714 & .0184 \\
\hline 32.Viljandi & 100 & 3 & 3.00 & .0300 & .0171 \\
\hline 33.Kilingi-Nõmme & 103 & 5 & 4.85 & .0485 & .0212 \\
\hline \multicolumn{1}{|c|}{ 1-33 in total } & 4300 & 230 & 5.35 & .0535 & .0034 \\
\hline
\end{tabular}




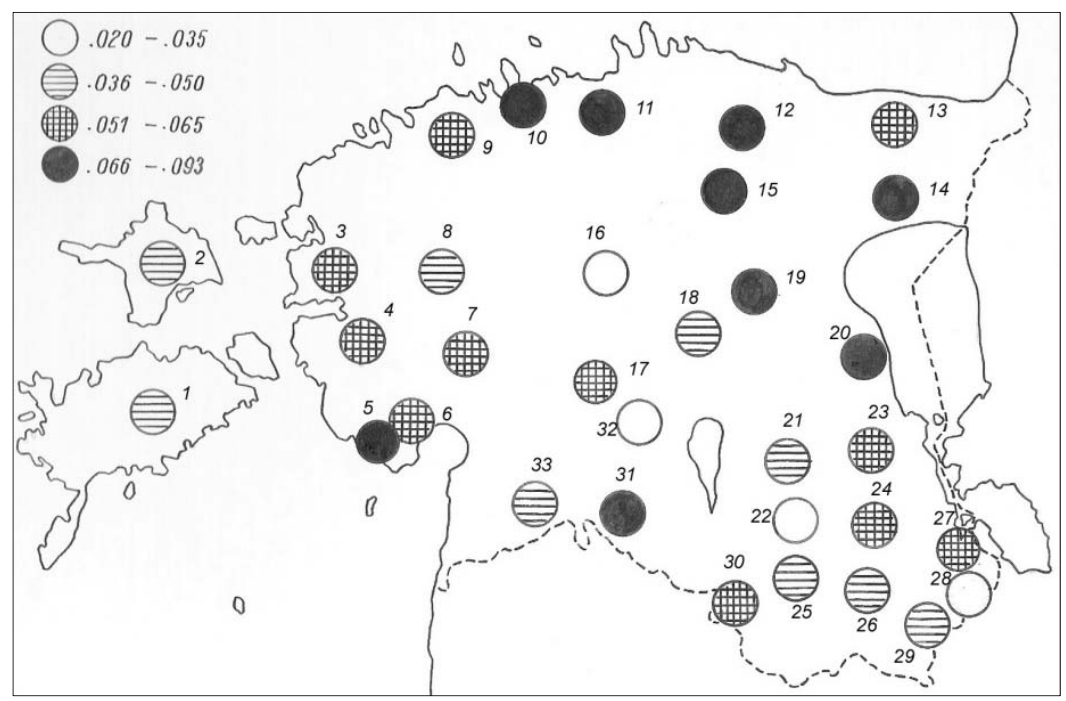

Fig. 3. Distribution of colour blindness $(c b)$ gene.

In the distribution of colour blindness, regional and racial differences occur. In Europoid populations colour vision deficiency is higher than in Mongoloids [9]. In comparison with some other European populations, the mean percentage of Estonians' colour blindness is comparatively low (Table 4). Frequency of colour blindness in Latvians in Alūksne and Varaklāni is similar to that of Central and South-West Estonians. On the territory of Northern Eurasia the mean frequency is 5.5\%, varying in the limits of $0.0 \%-24.0 \%$ [6:303]. Territory with the frequency below the mean $(0.0 \%-4.3 \%)$ embraces the central and north-eastern regions of Siberia. Towards north and south and southwest the frequency increases. The highest frequency of colour blindness is found on the territory of Belarus with a nucleus in Grodnensk region - 24.1\% [6:303]. 
Table 4. Frequency of colour blindness in various populations

\begin{tabular}{|l|c|c|c|}
\hline Population & $\mathrm{N}$ & $\%$ & Sources \\
\hline Estonians & 4300 & 5.3 & {$[11]$} \\
\hline Estonians & 235 & 6.2 & {$[27]$} \\
\hline Latvians (Alūksne) & 90 & 4.4 & {$[11]$} \\
\hline Latvians (Varaklāni) & 76 & 4.0 & {$[11]$} \\
\hline Vepsians & 103 & 7.8 & Author's data \\
\hline Hungarians (Transcarpathia) & 201 & 4.5 & Author's data \\
\hline Norwegians & 9049 & 8.0 & {$[9]$} \\
\hline Scots & 464 & 7.8 & {$[9]$} \\
\hline Germans & 1000 & 7.5 & {$[9]$} \\
\hline American Indians & 392 & 2.0 & {$[9]$} \\
\hline Congo Blacks & 929 & 1.7 & {$[9]$} \\
\hline
\end{tabular}

Thus, the survey showed genetic heterogeneity in the traits of taste sensitivity to PTC and colour blindness in Estonians; the greatest genetic differences were observed in the West-East direction (as in the other genetic characteristics of polymorphic systems [11,12]). On the West Estonian islands and on the West Estonian coast the percentage of nontasters of PTC is higher than anywhere else in Estonia. Frequency of colour blindness is higher in North, North-East and East Estonia; its mean frequency on the rest of the territory is lower. The genetic diversity in various traits seem to be a trace of the historical development of the Estonian nation.

\section{ACKNOWLEDGEMENTS}

The study was undertaken in the framework of the target funded research project of the Estonian Government (SF0130012s08).

\section{REFERENCES}

1. Allison A. C., Nevanlinna H. R. (1952) Taste deficiency in Lappish and Finnish populations. Ann. Eugen. Annals of Eugenics, 17, 113114.

2. Eriksson A. W., Fellmann J., Forsius H., Lehmann W. (1970) Phenylthiocarbamide tasting ability among Lapps and Finns. Human Heredity, 20, 623-630. 
3. Forrai G., Bánkövi G. (1968) Taste sensitivity to P.T.C. in Hungarian school children. Acta Genetica et Statistica Medica, 18, 137-144.

4. Fox A. L. (1932) The relationship between chemical constitution and taste. Proceedings of the National Academy of Sciences of the United States of America (Washington), 18, 115-120.

5. Gene Pool and Genogeography of Population, I (2000) Gene Pool of Population of Russia and Contiguous Countries (Ed. Yu. G. Rychkov), Saint Petersburg: Nauka.

6. Gene Pool and Genogeography of Population, II (2003) Genogeographical Atlas of Populations of Russia and Contiguous Countries (Ed. Yu.G. Rychkov), Saint Petersburg: Nauka.

7. Harris H, Kalmus H. (1949) The measurement of taste sensitivity to phenylthiourea (P.T.C.). Ann.Eugen., 15, 24-31.

8. Harris H., Kalmus H. (1951) The distribution of taste thresholds for phenylthiourea of 384 sib pairs. Ann.Eugen., 16, 226-230.

9. Harrison G. A., Weiner J. S., Tanner J. M., Barnicot N. A. (1964) Human Biology. London: Oxford Univ. Press.

10. Heapost L. (1972) Andmeid mõnede antropoloogiliste tunnuste esinemisest Eestis. Eesti geneetikute ja selektsionääride I konverentsi materjalid. Tallinn, 63-64.

11. Heapost L. (1994) Populatsioonigeneetilised tunnused eestlastel. K. Mark, L. Heapost, G. Sarap. Eestlaste antropoloogia seoses etnogeneesi küsimustega. Tallinn: Teaduste Akadeemia Kirjastus, 110-196.

12. Heapost L. (2000) A Population Genetic Characterization of Estonians. Anthropologisher Anzeiger, 58, 2, 137-154.

13. Kajanoja P. (1972) A Contribution to the physical anthropology of the Finns. Variations of the ABO, Rhesus, MN, P and Lewis blood group frequencies, PTC taste ability and colour blindness. AASF Annales Academiae Scientarum Fennicae. Series A, V, 153.

14. Kajanoja P., Schlygina N. V. (1986) Somatology and phenylthiocarbamide (PTC) taste ability of the Bashkirs. AASF, Series A, V, 175, 49-57.

15. Kim U. K., Jorgenson E., Coon H., Leppert M. Risch N. et al.(2003) Positional cloning of the human quantitative trait locus underlying taste sensitivity to phenylthiocarbamide. Science, 299, 1221-1225.

16. Lessa A. (1970) Anthropobiologie et anthroposociologie de Macao. L'histoire et les hommes. These-Tolouse.

17. McKusick V.A. (1983) Mendelian Inheritance in Man. 6th Edition. Maryland, US: John Hopkins University Press.

18. Schwidetzky I. (1962) Die neue Rassenkunde. Stuttgart 
19. Vuks G. (2004) Inimene kui mõõteriist. Horisont, 1, 32-35.

20. Widström G, Henschen A. (1963) The relation between P.T.C. taste response and protein bound iodine in serum. Scandinavian Journal of Clinical and Laboratory Investigations, 15, Suppl. 69, 257-261.

21. Wooding S. (2006) Phenylthiocarbamide: A 75-Year Adventure in Genetics and Natural Selection.

22. Ибраимов А. И., Байбурина С. Х., Кожухова А. С. (1977) Изучение способности ощущать вкус фенилтиокарбамида (РТС-тест) среди населения проживающего в Киргизии. Генетика, 13, 2, 330-336.

23. Кайанойа П. (1982) Способность к вкусовому ощущению фенилтиокарбамида у некоторых финно-угорских народов. Финноугорский сборник, Москва: Наука, 187-190.

24. Рабкин Е.Б. (1954) Полихроматические таблицы для исследования цветоощущения. Москва.

25. Рычков Ю.Г., Бородина С. П. (1969) Гиперсенситивность к фенилтиомочевине в одном из изолятов Сибири. Генетика, V, 3, 116123.

26. Саливон И.И., Тегако Л.И., Микулич А.И. (1976) Очерки по антропологии Белоруссии. Минск.

27. Серебровская Р.И. (1930) Генетика дальтонизма. Мед.-биол. журн., 4-5, 329.

28. Хазанова А.Б., Шамлян Н. П. (1970) К антропологии и популяционной генетике лопарей Кольского полуострова. Вопросы антропологии, 34, 71-78.

\section{Address for correspondence:}

Leiu Heapost

Department of Archaeobiology and Ancient Technology

Institute of History, University of Tallinn

Rüütli 6, EE-10130 Tallinn, Estonia

E-mail: leiu.heapost@ai.ee 